Wilfrid Laurier University

Scholars Commons @ Laurier

Kinesiology and Physical Education Faculty

Publications

Kinesiology and Physical Education

2011

\title{
A Path to Peace: Thoughts on Olympic Revenue and the IOC/ USOC Divide
}

Tim Elcombe

Wilfrid Laurier University, telcombe@wlu.ca

Stephen Wenn

Wilfrid Laurier University, swenn@wlu.ca

Follow this and additional works at: https://scholars.wlu.ca/kppe_faculty

\section{Recommended Citation}

Elcombe, Tim and Wenn, Stephen, "A Path to Peace: Thoughts on Olympic Revenue and the IOC/USOC Divide" (2011). Kinesiology and Physical Education Faculty Publications. 14.

https://scholars.wlu.ca/kppe_faculty/14

This Article is brought to you for free and open access by the Kinesiology and Physical Education at Scholars Commons @ Laurier. It has been accepted for inclusion in Kinesiology and Physical Education Faculty Publications by an authorized administrator of Scholars Commons @ Laurier. For more information, please contact scholarscommons@wlu.ca. 


\title{
A Path to Peace: Thoughts on Olympic Revenue and the IOC/ USOC Divide
}

\section{Tim Elcombe Stephen Wenn}

\begin{abstract}
U.S. Public Law 95-606 (otherwise known as the Amateur Sports Act), passed in 1978, has contributed significantly to the relationship between the United States Olympic Committee (USOC) and the International Olympic Committee (IOC) for the past thirty years. Exclusive rights to the use of Olympic marks and emblems in the U.S. territory granted to it in the Amateur Sports Act were leveraged by the USOC to obtain amounts of Olympicgenerated revenue from the sale of television rights fees and major corporate sponsorships far larger than any of the other National Olympic Committees (NOCs) recognized by the IOC. This privileged financial position has become a divisive issue for the USOC, IOC, and the world's 204 other NOCs. The IOC and USOC have agreed to commence discussions towards the establishment of a revised method to distribute Olympic revenue to members of the Olympic Tripartite (IOC, NOCs, and International Sport Federations). We suggest broadening this discussion to include a move to increase the amount of money from these sources transferred to Olympic Organizing Committees (OCOGs) to support a more formalized legacy plan for Olympic athletic facilities in host cities, and adding a new sponsor category to the existing corporate sponsorship program, The Olympic Partners (TOP), to enhance the IOC's commitment to social responsibility and sustainability. We also propose a new formula for the distribution of Olympic television and corporate sponsorship revenue as a means of contributing to this dialogue that must target a mutually acceptable resolution in order to foster a more harmonious working relationship between the IOC and USOC.
\end{abstract}

Stephen Wenn is Professor, Kinesiology and Physical Education, Wilfrid Laurier University in Waterloo, Ontario, Canada. He holds a PhD in Exercise and Sport Science from Penn State University (1993), and specializes in the history of the Olympic Games with a research emphasis on television rights negotiations and corporate sponsorship. $\mathrm{He}$ is a co-author of Selling the Five Rings: The International Olympic Committee and the Rise of Olympic Commercialism (Salt Lake City, University of Utah Press, 2002, rev. ed., 2004), and is lead author on a soon-to-be- released book entitled, Tarnished Rings: The International Olympic Committee and the Salt Lake City Bid Scandal (Syracuse, N.Y: Syracuse University Press, 2011).

Tim Elcombe is Assistant Professor, Kinesiology and Physical Education, Wilfrid Laurier University in Waterloo, Ontario, Canada. He holds a PhD in Kinesiology from Penn State University (2005), and specializes in sport philosophy and ethics with a research emphasis on the application of pragmatism to issues in sport. 


\section{Introduction}

Tn early 2011, the IOC is preparing to vote in July for the right to host the 2018 Olympic Winter Games, an honor chased by Annecy (France), Munich (Germany), and Pyeongchang (South Korea), and continues to liaise with British organizers during the crucial run up to the 2012 London Olympics. Both tasks are justifiably absorbing the attention of IOC officials; however, their energies are also being expended to solve a dispute concerning the distribution of Olympic revenue, which has compromised IOC/USOC relations in recent years.

The dispute dates to the 1980s, when the USOC successfully leveraged its exclusive rights to the use of the Olympic rings in U.S. territory to secure sums of money from domestic Olympic television contracts and the revenue accrued by the Olympic Program (now The Olympic Partners, TOP), a worldwide corporate sponsorship program conceived by former IOC President Juan Antonio Samaranch in order to diversify the Olympic Movement's revenue base, that was both envied and resented by the world's other NOCs, leaders of the International Sport Federations (ISFs), and IOC members based in Europe. The envy and resentment rose to such levels that the efforts of Chicago to acquire the right to host the 2016 Olympic Games were compromised. Recent productive dialogue between IOC executives and the USOC's leadership tandem of Larry Probst and Scott Blackmun offers the possibility for an era of improved bilateral relations, but this desirable outcome hinges on identifying and enacting mutually acceptable changes to the current distribution of Olympic commercial revenue.

In this paper, we offer our thoughts on how the IOC and USOC might approach the immediate need to reach an agreement (in advance of a 2013 deadline), while also exploring means of improving financial support for Olympians from developing nations, enhancing the post-Olympic use of Olympic venues, and extending the Olympic Movement's commitment to sustainability.

\section{Background}

In the 1970s, a widespread consensus existed in the United States that a dysfunctional managerial support structure compromised the efforts of the country's athletes on the international stage, most notably in Olympic competition. Soviet and East German athletes increasingly overshadowed U.S. Olympians in the 1960s and 1970s, and in a Cold War environment such a reality required redress. Washington lawmakers, who found their motivation to take action in the wake of the country's poor showing at the $1972 \mathrm{Mu}$ nich Olympics, targeted a solution for the internecine disputes between the National Collegiate Athletic Association (NCAA) and the Amateur Athletic Union (AAU), both of whom had long jockeyed for power and authority in U.S. Olympic matters. This rivalry was viewed as a major contributing factor to the malaise concerning U.S. Olympic fortunes. Passed by U.S. legislators in 1978, Public Law 95-606, more commonly known as the Amateur Sports 
Act (ASA), reflected the government's effort to streamline the administration of the nation's Olympic affairs.

The new administrative framework of the USOC, birthed by the ASA, resulted in the emasculation of the AAU, removing its national governing status for eight Olympic sports. This action placated the NCAA whose withdrawal from the U.S. Olympic scene in 1972 occurred as a result of its disenchantment with the AAU's power. Authority of U.S. Olympic affairs was placed squarely under the auspices of the revamped USOC. ${ }^{1}$ While the USOC's administrative structure required further renovation in ensuing years, and excessive turnover at the executive level plagued the organization in the last decade, ${ }^{2}$ the ASA (modified and rebranded as the Ted Stevens Olympic and Amateur Sports Act in 1998) ${ }^{3}$ confirmed the USOC's control of Olympic-related decision making in the United States.

In 1978, few U.S. federal legislators were likely to have perceived the seeds of conflict they sowed between the USOC and the IOC. But in delivering peace to the U.S. Olympic community, Washington politicians established a second theater of conflict. American legislators granted the USOC the exclusive rights to the use of the Olympic five-ring logo

But in delivering peace to the U.S. Olympic community, Washington politicians established a second theater of conflict. and other related marks and emblems in U.S. territory. ${ }^{4}$ This decision occurred before the IOC attempted to secure exclusive ownership of the five-ring logo in the early 1980s, via the World Intellectual Property Organization, ${ }^{5}$ and preceded the IOC's emergence as an economic juggernaut in the 1980s under Juan Antonio Samaranch, the IOC's seventh President. As a result of the powers granted to the USOC under the legislation, the ASA has been a significant factor in shaping IOC/USOC relations since the early 1980 s. $^{6}$

As the value of Olympic television rights climbed, and Samaranch's plans for diversifying the IOC's revenue base by establishing an international corporate sponsorship program evolved, the USOC soon grasped the economic value of its domestic ownership of the Olympic rings. Negotiations between the IOC and USOC ensued. Without sponsor access to the lucrative U.S. market, TOP would have been still-born. Samaranch and his IOC colleagues also understood the futility of a legal challenge to the ASA. These facts compelled the IOC to reach an agreement with the USOC. In 1985, the IOC ceded 15 percent of all revenue accrued by Samaranch's brainchild, TOP, to the USOC in exchange for waiving its exclusive rights to the use of the logo in the United States. ${ }^{7}$ The following year, as a result of the USOC's threat to prevent advertisers' use of the Olympic rings in commercials on U.S. Olympic broadcasts in 1988, the IOC agreed to send \$15 million to the USOC (an expense shared equally by the IOC and the Calgary and Seoul Olympic Organizing Committees), and transfer 10 percent of all future (1992 and beyond) U.S. Olympic television contracts to Colorado Springs, the site of the USOC's headquarters and its principal training facility for 


\section{SAIS Review WINTER-Spring 2011}

the country's aspiring Olympians. ${ }^{8}$ This agreement was enshrined in the Broadcast Marketing Agreement (BMA) reached between the two bodies in March 1986.

Buoyed by the legal weight of the ASA, the USOC continues to enjoy its singular financial status as the "Have NOC" with respect to IOC-generated revenue with its share dwarfing those allocated to the other 204 NOCs worldwide. Between 2005 and 2008 the USOC received \$298,154,000 via TOP, its share of the U.S. Olympic television contracts, and television deals in other markets. The remaining 204 NOCs shared $\$ 393,082,000 .^{9}$

Samaranch's presidency (1980-2001) witnessed numerous skirmishes between the USOC, which sought to enhance the terms of the agreements concerning the distribution of television and corporate sponsorship money, and the IOC, which resisted these overtures. The USOC pursued these changes in face-to-face discussions with IOC officials and through its lobbying efforts on Capitol Hill. ${ }^{10}$ In seeking assistance from Washington politicians, the USOC hoped for legislative action that would enhance its powers granted under the ASA. In particular, the USOC wanted the authority to negotiate the U.S. television deals in order to set its share of television revenue without the need for IOC input.

Jacques Rogge's presidency (2001-present) has not been immune to these tensions. Currently, the USOC receives 12.75 percent of the U.S. television contract and 20 percent of the money generated by the TOP program (remembering that a portion of the global sum from the program takes the form of VIK, or value-in-kind donations). In the past three years, the IOC's European members unleashed their (verbal) arrows in an attempt to diminish the USOC's share of these revenue sources, noting that one of the USOC's major arguments-namely that the U.S. market provides the vast majority of the money-is no longer valid. European and Asian television networks are providing increasing sums of money and have been for over a decade, while non-American multinational companies outnumbered American-based ones in support of the most recent Olympic Winter Games in Vancouver. ${ }^{11}$ The USOC, under the chairmanship of Peter Ueberroth, was unwilling to approve any proposal that would reduce the overall amount of money flowing to the USOC. Given that this money funds 50 percent of the USOC's budget, his stance was predictable. ${ }^{12}$

Chicago 2016, the bid committee championing the city's pursuit of the 2016 Olympic Games, was caught in the crossfire between the IOC and

\section{Anti-American sentiment within the IOC, largely whipped up by its European cohort ... compromised Chicago's efforts.}

USOC leading up to the final vote at the IOC's Copenhagen Session in October 2009. AntiAmerican sentiment within the IOC, largely whipped up by its European cohort who pressed for a reduction in the USOC's share of Olympic revenue, compromised Chicago's efforts. Larry Probst, who succeeded Ueber-
roth in late 2008, agreed to engage in discussions with IOC officials com- 
mencing in 2013 concerning a new distribution method (to be implemented post-2020) when he gleaned that Chicago's grip on the Olympic chalice had been loosened, in no small measure due to the ongoing conflict. It was too little, too late. Aided by its adept staging of the 2007 Pan-American Games, Rio de Janeiro's successful bid also benefited greatly from its representatives' passionate call for the Olympics to be awarded to South America for the first time. ${ }^{13}$

The IOC left a good deal of money on the table by walking away from what would have been an energized U.S. corporate community and an extremely competitive U.S television rights environment if Chicago prevailed. Chicago's loss was also a financial blow for the USOC because its domestic sponsorship program would have benefited from the selection of the U.S. city. Furthermore, U.S. television executives would pay more for the U.S. Olympic television rights if the Games had been awarded to Chicago as opposed to any of the other finalists (Rio de Janeiro, Madrid, and Tokyo). This, too, would have worked in the USOC's financial favor because of its percentage share of the U.S. television contract.

Undoubtedly, one can make a solid argument from the IOC's perspective for extending the Olympic brand to South America, and demonstrating regard for the ambulatory mission of the Olympic Games. However, a more harmonious working relationship between the IOC and USOC is in the best interests of the Olympic Movement. Powerbrokers within America's Olympic hierarchy understand that any U.S. city's quest to host an Olympic festival will founder on the rocks in the absence of a resolution. Recent outreach efforts by the USOC's new CEO, Scott Blackmun, and Larry Probst, augur well for a respectful future dialogue between the two sides. ${ }^{14}$ Further confirmation that the A more harmonious working relationship between the IOC and USOC is in the best interests of the Olympic Movement. Powerbrokers within America's Olympic hierarchy understand that any U.S. city's quest to host an Olympic festival will founder on the rocks in the absence of a resolution. two sides were looking for common ground on revenue matters occurred in September 2010, when the USOC agreed to send \$18 million to the IOC to solve the "games cost" issue in relation to the 2010 Vancouver Olympic Winter Games and the 2012 London Olympics. ${ }^{15}$

\section{Crux of the Dispute}

The USOC's case for a disproportionate share of Olympic revenue generated from the sale of U.S. television rights and TOP sponsorships rests largely on the existence of the ASA, a U.S. federal statute. With respect to Samaranch's 


\section{SAIS Review WINTER-SPRING 2011}

plans for TOP, the USOC claimed that they encroached on its exclusive rights to the use of Olympic marks and emblems in the U.S. market, and its consent to the proposal required financial concessions from the IOC. USOC officials argued that the U.S.-based companies that dominated the prospective list of multinationals that might value the use of the Olympics as an international marketing platform in the mid-1980s otherwise would have been pursued as domestic (USOC) sponsors. This (alleged) financial sacrifice triggered its decision to uphold the terms of the ASA and seek compensation. ${ }^{16}$

The USOC's belief that U.S. companies would gravitate to TOP sponsorships proved accurate as they provided 77.8 percent of the $\$ 96$ million raised by the program in its inaugural quadrennial (1985-1988). ${ }^{17}$ When the IOC agreed to the Broadcast Marketing Agreement in 1986, U.S. television networks, $\mathrm{ABC}$ and $\mathrm{NBC}$ respectively, provided the lion's share of global television revenue (83.7 percent) for the upcoming 1988 Calgary Winter and Seoul Summer Olympics (\$609 million of the $\$ 727.5$ million global sum). ${ }^{18}$ The IOC could neither deny its financial dependence on the U.S. market, nor expect any U.S. court to overturn the terms of the ASA. The USOC benefited greatly from the financial boost afforded by the evolution of TOP and the signing of the BMA.

Over the past two decades, as the influences of globalization wrought major changes to the international economic order, the U.S. market's percentage contribution to IOC coffers declined. For the 2009 to 2012 quadrennial, American firms will supply 52.6 percent and 44 percent of the television revenue and TOP funds respectively; however, recent deals reached with Procter \& Gamble and Dow Chemical will enhance the latter figure. ${ }^{19}$ IOC officials counter the USOC's argument concerning U.S.-based companies' contribution to the marketing program's overall revenue with the knowledge that these businesses employ people in many countries and rely on revenue generated by the sale of their products around the globe. In a globalized economy, the TOP fees paid to the IOC also emanate from subsidiaries located outside the United States. At the IOC's headquarters in Lausanne, Switzerland, there is resentment that the U.S. government does not fund a portion of the USOC's operational budget in the fashion that other federal governments do for NOCs around the globe. The IOC, in this sense, believes it is funding 50 percent of the USOC's budget, and considers this situation untenable. ${ }^{20}$ Without access to the U.S. market, USOC officials remind their IOC counterparts, the value of a TOP sponsorship would be significantly diminished-less money for everyone. Then, too, NBC has still been supplying over 50 percent of the sum raised from the sale of Olympic television rights around the globe in recent years. And so it goes.

At this time, we wish to propose specific suggestions for the IOC and USOC in order to resolve their differences on the distribution of Olympic television and corporate sponsorship revenue, and in the process, better serve the needs of athletes worldwide, while further advancing the IOC's commitment to social responsibility, safeguarding the financial interests of taxpayers in Olympic host communities, and promoting sustainability. 


\section{A Path to Peace}

The path to peace for Olympic stakeholders requires consideration of the history of the IOC's policies governing distribution of commercial revenue. In 1966, when the IOC passed its first formal set of guidelines for the allocation of television revenue (known as the Rome Formula), the Olympic Organizing Committee (OCOG) received 66.7 percent of the money. The remaining 33.3 percent was apportioned equally to the IOC, NOCs, and ISFs. This formula applied for the first time to money from the sale of television rights to the 1972 Sapporo and Munich Olympic Games, ${ }^{21}$ and it served as the basis for the distribution of revenue through the 1994 Lillehammer Olympic Winter Games despite numerous (and often successful) efforts of OCOG leaders in the 1970s and 1980s to further enhance their shares of the revenue pie. ${ }^{22}$ In response to these machinations, the IOC assumed an increasingly greater profile in the negotiations with television network representatives in the 1980s in order to prevent the OCOGs from signing contracts detrimental to the IOC's financial interests. ${ }^{23}$ The IOC established a new distribution policy in advance of the 1996 Atlanta Olympics with 60 percent granted to the OCOG, and 40 percent directed to the IOC and its Olympic family partners, a practice that continued through the 2002 Salt Lake City Olympic Winter Games.

In 1995, Samaranch successfully championed a move to further enhance the amount of money flowing to Olympic organizations. His plan to reduce an OCOG's share of television money to 49 percent (down from 60 percent), and increase the Olympic Movement's share to 51 percent (up from 40 percent) was challenged within the Executive Board by senior IOC members, Richard Pound, Anita DeFrantz, and Kevan Gosper. "An important contribution to public sympathy for the Games," stated Pound, the longtime chief negotiator of Olympic television deals in the U.S. and beyond, "lay in the IOC's being able to say that most of the revenue went towards organizing the Games." Paring the OCOG's share "was neither necessary nor popular," he continued, and should not be undertaken "unless a need for more revenue within the Olympic family could be demonstrated." In addition, he warned that if the IOC's share of television revenue increased, the IOC could expect an approach from the USOC for an increase on its current ten percent share. ${ }^{24}$ Anita DeFrantz labeled a decision to limit an OCOG's portion to 49 percent, "a punitive gesture." ${ }^{25}$ Gosper did not like the optics of increasing the Olympic Movement's share so quickly after the most recent change in advance of the Atlanta Olympics or moving past the 50 percent line. ${ }^{26}$

Samaranch clearly wanted to distribute more money to the NOCs and ISFs. He knew that the time to move forward with this change, to come into effect for the 2004 Olympics, was in 1995 or 1996 while the 2004 bid cities were actively seeking the right to host the Games. They were far less likely to voice any opposition when attempting to court the IOC's favor than after a site had been selected in 1997. ${ }^{27}$ Holland's Pál Schmitt backed Samaranch's plan to increase the amounts flowing to the ISFs and NOCs, as did fellow 


\section{SAIS Review WINTER-Spring 2011}

Executive Board member, Ashwini Kumar of India. Alexandre de Merode of Belgium supported Samaranch's proposal stating that the IOC's expenses might increase in the future if athletes demanded money for their participation in the Olympics. Samaranch's victory was not a resounding one, as the motion passed by a vote of 5-4 with 1 abstention. ${ }^{28}$ When François Carrard, the IOC's Director General, asked the group whether he should announce the change at the upcoming lunchtime press briefing, a clearly displeased Pound offered that "if the Executive Board was proud of its decision, it should announce it straightaway." 29

When the IOC leadership sold this change in the public forum, one of the principal supporting arguments was that the OCOG's diminished share of television revenue was offset by the increasing sums available from the TOP program. Our position on the future distribution of television revenue (in terms of the percentage share directed to the OCOGs) falls closer to the opinion voiced by Richard Pound, when the IOC pondered the change in September 1995. It is the OCOG and the host community that must stage an Olympic festival and who bear the responsibility for ensuring that the Games are well organized, complete with the facilities, transportation plan, required accommodations, and necessary security. We are unconvinced that the ISFs require the substantial sums flowing to them in the wake of the 2004 Athens Olympics. The ISFs are not required to abandon staging their World Championships in an Olympic year, although this was an action some took in the past, and therefore can not claim an inability to generate their own revenue in an Olympic year as a justification for the receipt of Olympic-generated money. In the 2005-2008 quadrennial, over \$420 million was distributed to the ISFs governing sports on the Olympic Winter and Olympic programs. ${ }^{30}$ We are more sympathetic to the needs of the NOCs who must feed, clothe, and transport their athletes who participate in Olympic Games, and spearhead the promotion of the Olympic Movement and its values in their respective countries. ${ }^{31}$ At the close of 2009, the IOC's reserve fund rested at $\$ 466$ million. The organization is in a position to re-direct some of its share of Olympic revenue to other entities. Admittedly, until the IOC witnesses a decline in the number of cities willing to accept the financial risk of hosting the Games under the current distribution method for television and corporate sponsorship revenue, the IOC's senior leadership likely lacks the motivation to reduce the amount of money that the members of the Olympic family receive. ${ }^{32}$ Samaranch hoped that the enhanced revenues would empower the NOCs and ISFs to further develop sport in a global context, but it cannot be ignored that when money flows, good feelings follow, and this also fueled Samaranch's use of money to assist in maintaining good relations with the ISFs and NOCs in the latter years of his presidency.

Our prescription for change favors the interests of the OCOGs and challenges leaders in the Olympic Tripartite (the IOC, NOCs, including the USOC, and ISFs) to act in the best interests of Olympic athletes and the communities that accept the daunting task of hosting an Olympic Games. While they will likely not be popular, at first glance, among many of those 
affiliated with the IOC, NOCs, and ISFs, all of whom experience a drop in their shares of Olympic revenue under the plan, our proposals are designed to prompt a meaningful and necessary discussion in which all of the aforementioned agencies justify the large sums of money channeled to them.

\section{Television Dollars}

When the IOC Executive Board, at Samaranch's urging, altered the method of distributing television revenue from the $60 / 40$ (OCOG/Olympic Movement)

Our prescription for change challenges leaders in the Olympic Tripartite ... to act in the best interests of Olympic athletes and the communities that accept the daunting task of hosting an Olympic Games. split to the $51 / 49$ (Olympic Movement/OCOG) formula, the USOC pushed for a larger share than the 10 percent of the U.S. contract it had received since the establishment of the Broadcast Marketing Agreement. Beginning with the 2004 Athens games, the two sides agreed to divide the money from the U.S. television contract into five portions: 49 percent for the OCOG and equal shares of 12.75 percent to the IOC, NOCs, ISFs, and USOC. All non-U.S. television contracts adhered to the 51/49 distribution formula; however, it should be noted that the USOC did not receive a direct share from this revenue source. This plan remained in effect through the Turin/Beijing (2005-2008) quadrennial.

Today, the USOC maintains its 12.75 percent share of the U.S. television contract, while the IOC Executive Board determines the distribution of the remaining portion of the Olympic Movement's share of the U.S. and non-U.S. television contracts following negotiations with the NOCs and ISFs. The OCOGs in the current (Vancouver and London) and subsequent quadrennials (Sochi and Rio) receive what is termed an "IOC Contribution" in real U.S. dollars that does not have a direct percentage link to television revenue from the U.S. or non-U.S. television contracts. It seems that OCOGs now work under the assumption that they will not receive less in terms of this "IOC Contribution" than the preceding OCOG, that there may not necessarily share in any increases in revenue derived from the sale of Olympic television rights. Our preference is that the IOC employs a distribution formula with defined percentages, if for no other reason than transparency, and as a result, our proposals will use the former distribution plan as a base (Table 1).

We support a move to a 55/45 (OCOG/Olympic Movement) split, with a share of 11.25 percent flowing to the USOC, and 33.75 percent distributed among the ISFs, NOCs, and IOC. We propose to reduce the debt faced by many host communities by enhancing the funds available to the OCOGs from television revenue, in addition to financial support from TOP. The same 55/45 split would apply to all non-U.S. television contracts with the IOC, ISFs, and NOCs, sharing the Olympic Movement portion as per the current negotiations process; however, we advise that the NOCs' share not 


\section{SAIS Review WINTER-Spring 2011}

be reduced. If the USOC seeks to supplement its revenue in light of these reductions, it should approach its federal government, as do other NOCs, or ramp up its own domestic sponsorship efforts. ${ }^{33}$

\section{TOP Dollars}

Currently, half of the TOP revenue in any quadrennial is directed towards the Winter and Summer Organizing Committees (OCOGs), and the NOCs (forty percent) and the IOC (ten percent) receive the remaining half. Solving the IOC/USOC dispute must not deduct from funds earmarked for the OCOGs. Their fifty percent share remains sacrosanct, and we advise an eight percent augmentation for the establishment of an Olympic Facilities Management Agency (OFMA), which would ensure that Olympic facilities serve as temporary, but world-class, training facilities for aspiring Olympians as well as a breeding ground for coaches. This legacy plan should be instituted for a minimum of three years and would need to be thoroughly outlined during the original bid process. The NOCs and each OFMA would also need to establish cost-sharing plans for accommodations for those travelling to the site following the close of the Olympic and Paralympic Games. Many bids revolve around the idea that an Olympic Village serve as a source of low-income housing for the host community after an Olympic festival. We do not seek to alter the mindset of bid committees concerning the merit of this type of initiative, but we suggest perhaps twenty percent of the Olympic Village be diverted to housing visiting athletes and coaches for a three-year period as a critical element in maintaining the functionality of a world class training facility. The OFMA could also make use of this accommodation space as a youth hostel when not housing aspiring Olympians, as a source of additional revenue. To assist in the generation of local jobs, people living within the low-cost housing community could be employed as members of the cleaning and maintenance staff of the portion of the Olympic Village retained as an element of the athletic training infrastructure.

The additional eight percent directed at the OCOGs also has ramifications for the IOC and USOC: the IOC, cushioned by its $\$ 466$ million reserve, would accept a 7 percent share, the NOCs would still receive 20 percent, and the USOC's share would fall to 15 percent. This reduction returns the USOC's share to what it had been at the time of the program's inception, but still provides the USOC with a sizeable contribution, recognizes the financial contribution of the U.S. market and the ASA, and maintains the USOC in a revenue-sharing position not enjoyed by any of the world's other 204 NOCs. With a 15 percent share of TOP revenue and an 11.25 percent share of the U.S. television contract, not to mention its share of the television money sent to the NOCs through Olympic Solidarity, the USOC maintains its privileged position. ${ }^{34}$

\section{TOP Sustainability Partner: A New Initiative}

In addition to suggesting reformed strategies for the distribution of television contract and TOP revenue, our "path to peace" proposal includes the creation of a new sponsor category: the TOP Sustainability Partner. TOP 


\section{Table 1. Turin-Beijing and Proposed Formulas for Distribution of Television and TOP Revenue}

\section{Turin/Beijing Percent Share Proposed Percent Share}

OCOG IOC ISFs NOCs USOC

OCOG IOC ISFs NOCs USOC

US Television

$49 \quad 38.25$

12.75

$55 \quad 33.75$

11.25

Non US Television 49

51

$0^{\mathrm{i}}$

55

$45^{\text {ii }}$

$0 \mathrm{a}$

TOP Revenue $e^{\mathrm{iii}}$

50

$\begin{array}{lll}10 & 0 & 20\end{array}$

20

$\begin{array}{llll}58 & 7 & 0 & 20\end{array}$

15

${ }^{i}$ While not receiving a dedicated share of the non-U.S. television money, the USOC does receive a share of money, as do the other 204 NOCs, from the NOCs' portion of the 51 percent share for the Olympic Movement transferred through the Olympic Solidarity Program.

${ }^{i i}$ Despite the reduction in the Olympic Movement's share of non-U.S. television revenue from 51 percent to 45 percent, we propose the percentage of money directed to the NOCs remain constant.

iii The "Turin/Beijing Percent Share" formula for TOP Revenue, which is still used today, is employed for the distribution of contributions of the majority of TOP sponsors. For a limited number, based on product category, some modifications are made.

Sustainability Partner initiatives aim to make a difference in the social, economic, and athletic development of disadvantaged regions around the world by capitalizing on the Olympic Movement's global presence, supporting the IOC's stated commitment to enhancing sport as a tool for the improvement of social and human well-being, ${ }^{35}$ and addressing ongoing criticisms of the IOC and its dearth of social responsiblity initiatives.

Unlike traditional TOP sponsors, corporations vying for TOP Sustainability Partner status would submit proposals for a specified sustainability project addressing the UN Millennium Development Goals. These proposals would be equal in dollar worth to traditional TOP sponsors-currently around \$100 million-and 55-65 percent of total funds would go establishing a project in a developing nation. ${ }^{36}$ For example, programs could include building clean-water facilities, erecting hospitals or clinics dedicated to child and maternal health, or retrofitting factories to reverse the loss of environmental resources.

Rather than compete for TOP Sponsor status against other corporations within existing product or service categories (such as Coca Cola versus Pepsi Cola or Visa versus American Express), TOP Sustainability Partner applicants may come from any product or service category not already represented by current TOP Sponsors. For instance, the current TOP Sponsor list ${ }^{37}$ does not include a sporting apparel company, leaving the TOP Sustainability Partner category open to companies such as Nike, Adidas, or Reebok to submit proposals. Members of the IOC marketing commission, UN global sustainability consultancies, and other governmental and non-governmental institutions ${ }^{38}$ would comprise a bilateral commission that chooses, upon IOC Executive Board appproval, the successful TOP Sustainability Partners. Additionally, this committee would complete a semi-annual review of the 


\section{SAIS Review WINTER-Spring 2011}

state of on-going projects and the status of completed facilities in order to exhibit a sound monitoring practice for the fund.

The remaining 35 percent to 45 percent from the successful TOP Sustainability Partner's proposition would be earmarked to provide assistance to aspiring Olympians in financial need, as well as making funds available to help developing nations enhance their sport infrastructure. The IOC would create two separate funds by equally splitting the remaining 35 to 45 percent (approximately $\$ 35$ to 45 million, based on current TOP Sponsorship commitments). NOCs from developing nations could apply for support from one fund managed in Lausanne by IOC staff members to financially assist in clearly defined sporting infrastructure projects, such as stadia and training facilities. A special committee comprised of one active NOC representative nominated from each continent (and approved by the Association of Olympic Committees), as well as an ad hoc group from the current IOC Executive Board, including the Chairman of Olympic Solidarity and at minimum three other members of the Olympic Solidarity Commission, would decide which projects receive funding. NOCs that receive funds would be required to submit quarterly project reports until the construction phase of any project has concluded, complete with financial records, and semi-annual reports thereafter on the function of the facility in question for a period of five years.

The second fund, similarly controlled and managed by IOC personnel in Lausanne, would provide a reserve from which athletes can apply for need-based bursaries to offset clearly articulated training, equipment, or ancillary support costs. For instance, an Indonesian pole vaulter may apply for funds to cover expenses for a new carbon fiber pole, three weeks of expert coaching hosted at an Indonesian track and field facility, and training for two weeks at one of the proposed Olympic "legacy" sites. A committee consisting of an NOC representative from each continent as well as the existing IOC Athletes' Commission-a body comprised of athletes elected by fellow Olympians-would adjudicate the athlete bursary applications.

\section{Summary}

Our purpose in advancing these proposals concerning modifications to means employed to both distribute and generate Olympic revenue is multifold. First and foremost, we believe that the IOC and USOC must form a true partnership that resolves the current dispute and recognizes that the Olympic Movement is stronger when their mutual interests are served. Also, we sought to contribute to this dialogue. Second, we assert that impending discussions between the IOC and the USOC offer stakeholders in the Olympic Movement an important opportunity to reflect on issues extending well beyond the microcosmic situation involving Lausanne and Colorado Springs. Central among these issues is our belief that a greater proportion of the money generated from television rights sales and corporate sponsorship should be transferred to OCOGs. In addition, the ambulatory mission of the Games, while laudable, has created too many "white elephant" stadia 
and their potential benefits in terms of athlete development are not realized. Hence, we propose the development of a formalized three-year legacy plan for the use of Olympic facilities to support aspiring Olympians from around the globe. This plan would afford host cities (and their business communities) additional streams of revenue while athletes, coaches, and support staff visited for training purposes, not to mention the visitors and spectators who would spend money in the communities for any competitions (exhibition tournaments, regional or world championships) staged at the former Olympic facilities during the three-year period following the conclusion of the Games. Fourth, can this wider dialogue concerning the generation and distribution of Olympic revenue provide an opportunity for the IOC to augment its commitment to sustainability and social responsibility? We believe so, and this is why we have proposed the development of the TOP Sustainability Partners for companies seeking a hybrid sponsorship that would elevate their profile within the elite athlete and sport development domain (bursary program for athletes in need) as well as the developing world (NOC support), thus demonstrating their commitment to social responsibility (major infrastructural project in the developing world).

It is clear from the recent efforts of IOC officials and USOC representatives to open dialogue on the "games cost" issue that the possibility for a new era in terms of communication and trust between the two bodies is real. Their respective leaders deserve plaudits for making this happen. We believe that the next round of discussions concerning the USOC's share of Olympic revenue from television rights and corporate sponsorship offers avenues of discussion beyond the terms of their future financial relationship and that those same avenues of discussion provide means for the Olympic Movement to address the worthy goals of social responsibility and sustainability.

\section{Notes}

${ }^{1}$ Nancy Scannell, "New Bodies Suggested for USOC; Restructuring of USOC Recommended," Washington Post, January 13, 1977, p. D1; and, Nancy Scannell, "AAU-NCAA Conflict Nears Conclusion - Commentary," Washington Post, June 25, 1978, p. E7. Both articles were located through the LexisNexis search engine. See also, John T. Woolley and Gerhard Peters, The American Presidency Project [online]. Santa Barbara, CA., http://www. presidency.ucsb.edu/ws/?pid=23939 [January 11, 2010]. U.S. President Gerald Ford established the President's Commission on Olympic Sports (PCOS) through Executive Order 11868 in 1975 . The PCOS filed its 613-page, two volume antidote for what ailed the USOC and compromised the country's performance on the international sport stage in January 1977. These suggestions formed the basis of the changes outlined in the Amateur Sports Act signed by President Jimmy Carter in November 1978. For more on the Amateur Sports Act, see Thomas M. Hunt, "Countering the Soviet Threat in the Olympics Medals Race: The Amateur Sports Act of 1978 and American Athletics Policy Reform," The International Journal of the History of Sport 24 (2007): 796-818.

${ }^{2}$ Eddie Pells, "USOC Still Looking for Answers in the Wake of Chicago's Embarrassment in Vote for 2016 Olympics," October 3, 2009, http://blog.taragana.com/sports/2009/10/03/ usoc-still-looking-for-answers-in-wake-of-chicagos-embarrassment-in-vote-for-2016-olympics-34010/ [March 29, 2010]. Scott Blackmun is the USOC's seventh full-time or interim CEO since 2000. For an assessment of the challenges facing Blackmun who was hired in January 2010, see Bill Briggs, "USOC Struggles to Polish its Tarnished Image," msnbc.com, February 10, 2010, http://msnbc,msn.com/id/35147038/ [August 20, 2010]. 


\section{SAIS Review WINTER-SPRING 2011}

${ }^{3}$ Changes enacted in the Ted Stevens Olympic and Amateur Sports Act reflected the need to attend to a number of issues including the demise of amateurism, the USOC's responsibilities concerning the Paralympic Games, as well as a desire to improve athlete representation.

${ }^{4}$ For a complete text of the Amateur Sports Act, see, Amateur Sports Act of 1978, Pub. L. No. 95-606, 92 Stat. 3045 (1978). Anne Wall provided an interesting analysis of the power of the Olympic rings to generate revenue in the context of Salt Lake City's domestic sponsorship program, as well as the efforts of the USOC and Salt Lake organizers to protect their corporate sponsors from ambush marketing campaigns. See Anne M. Wall, "The Game Behind the Games,” Marquette Sports Law Review 12 (Spring, 2002): 557-581. Interestingly, Congressional action in 1978 reconfirmed powers already granted to the United States Olympic Association in 1950 at the time of its incorporation with respect to ownership of its then-shield logo and the Olympic rings. See United States Statutes at Large, 1950-1951, vol. 64, Part I: Public Laws and Reorganization Plans (Washington, D.C.: United States Government Printing Office, 1952), 901.

${ }^{5}$ These efforts were largely unsuccessful. A mere twenty-two countries signed WIPO's Nairobi Treaty to protect the Olympic emblem in the early 1980s. The U.S. representative at WIPO's Nairobi's conference did not sign the Treaty, and provided no explanation. Undoubtedly, the individual was aware of the conflict that would have been established with the pre-existing terms of the ASA. The logo's use in the public domain commenced in December, 1987, fifty years after Pierre de Coubertin's death. Coubertin designed the logo in 1913. The IOC considered establishing a new logo, but relied instead on internal copyright protections pursued by individual NOCs. Robert K. Barney, Stephen R. Wenn, and Scott G. Martyn, Selling the Five Rings: The IOC and the Rise of Olympic Commercialism (Salt Lake City: University of Utah Press, rev. ed. 2004), 156-163.

${ }^{6}$ A detailed analysis of this issue can be found in, Barney, Wenn, and Martyn, Selling the Five Rings, 168-180, 211-213, 225-226, 243-265, 267-277.

7 “IOC/ISL Meeting," May 14, 1985, Lausanne, "ISL Union with IOC” File; and, Minutes of the Meeting of the IOC Executive Board, Lausanne, May 28, 1985, pp. 177-178, International Olympic Committee Archives, Lausanne, Switzerland [hereafter cited as IOCA]. For a discussion of events, see Barney, Wenn, and Martyn, Selling the Five Rings, 172-175.

${ }^{8}$ Richard Pound (Chair, IOC Television Rights Negotiations Commission) to Juan Antonio Samaranch (IOC President), September 26, 1985; and, Richard Pound to Juan Antonio Samaranch, September 30, 1985, "Seoul 1988 TV-General II” File, IOCA. For the USOC's view, see George D. Miller (Secretary General, USOC) to Roone Arledge (President, ABC Sports), October 29, 1985, "Calgary 1988 TV-General” File, IOCA. The deliberations of the IOC Executive Board can be found in Minutes of the Meeting of the IOC Executive Board, Lausanne, February 11-12, 1986, pp. 5-7; and, Minutes of the Meeting of the IOC Executive Board, Seoul, April 22-24, 1986, pp. 4-5, IOCA.

${ }^{9}$ IOC Reference Service, e-mail message to Stephen Wenn, January 14, 2010.

${ }^{10}$ Barney, Wenn, and Martyn, Selling the Five Rings, 243-265.

${ }^{11}$ Philip Hersh, "IOC Official Rips USOC's Share of Olympic Funding," Chicago Tribune, June 3, 2008, http://www.chicagotribune.com/sports/chi-us-olympic-revenues-share,0,1220316. story [September 28, 2008]; "IOC, USOC to Revisit Olympic Revenue Sharing," CBSSports. com, June 4, 2008, http://sportsline.com/worldsports/story/10852373 [September 28, 2008]; and, "Dispute over Olympic Revenue Sharing May Impact Chicago Bid," USA Today, June 3, 2008, http://www.usatoday.com/sports/olympics/2008-06-03-chicago-share_N.htm [September 28, 2008].

${ }^{12}$ Hersh, "IOC Official Rips USOC's Share of Olympic Funding"; and, "Ueberroth: U.S. Business Drives Olympic Financial Engine,” October 11, 2008, http://universalsports.com/ news/article/newsid=301894.html [August 18, 2010].

${ }^{13}$ For an interesting in-the-moment analysis, see John Goodbody, "Rio de Janeiro Takes the World by Storm," The Sunday Times, October 4, 2009, http://timesonline.co.uk/tol/sport/ olympics/article6860138.ece [August 18, 2010]. Wenn placed Chicago's collapse in the wider context of IOC/USOC relations in, Stephen R. Wenn, "IOC/USOC Relations and the 2009 IOC Session in Copenhagen,” in Robert K. Barney, Janice Forsyth, and Michael Heine, eds., 
Rethinking Matters Olympic: Investigations into the Socio-Cultural Study of the Modern Olympic Movement: Proceedings of the 10th International Symposium for Olympic Research (London, Ontario: International Centre for Olympic Studies, 2010), pp. 60-75.

${ }^{14}$ Alan Abrahamson, "Scott Blackmun: Arguably the USOC's last best chance," UniversalSports. com, January 6, 2010, http://www.universalsports.com/blogs/blog=alanabrahamsonsblog/ postid=387006.html [January 15, 2010]; and, Stephen Wilson, "IOC and USOC look to resolve financial issue,” USA Today, April 27, 2010, http://www.usatoday.com/sports/ olympics/2010-04-27-2872487469_x.htm [May 2, 2010]. Peter Ueberroth's successor as Chairman of the USOC, Larry Probst, has also expended significant energies recently in an attempt to effect repair to IOC/USOC relations. Tripp Mickle, "Probst on USOC-IOC Relations: Time to Walk the Walk," February 11, 2010, http;//sportsbusinessdaily.com/ wintergames/entries/2010/Probst-on-usoc-ioc-relations-time-to-walk-the-walk [August $18,2010]$; and, Brian Gomez, "USOC Chair traveling the globe, mending ties with IOC," Colorado Springs Gazette, June 29, 2010, http://www.gazette.com/articles/usocchairmantravelingtheglobe-100995-mendingtieswithioc-.html [September 15, 2010].

${ }^{15}$ All NOCs, with the exception of the USOC, had contributed in the past to a fund that helped defray costs of the operation of a number of IOC commissions, anti-doping operations, and the Court of Arbitration for Sport. This resolution advances the timeline for the opening of discussions on the larger matter of Olympic revenue distribution before the planned date (2013) for the commencement of talks. "USOC and IOC reach agreement in financial dispute," USA Today, September 9, 2010, http://www.usatoday.com/sports/ Olympics/2010-09-09-usoc-ioc-agreement_Nhtm [September 13, 2010].

${ }^{16}$ This leverage point for the USOC has lost a good measure of its weight in the ensuing years. A large U.S. multinational with designs on expanding its reach within a global economy would by no means see significant value in an Olympic sponsorship platform if limited to its use in the U.S. market alone. There seems less support today for the USOC's position that a U.S. company by default would pursue a USOC sponsorship in the absence of the TOP program that operates on a global basis.

${ }^{17}$ Tripp Mickle, "IOC Shifts from Dependence on U.S. Revenue, Street \& Smith's SportsBusiness Journal, October 12, 2009, http://www.sportsbusinessjournal.com/article/63810 [April 15, 2010].

${ }^{18}$ Ibid.

${ }^{19}$ Ibid; “IOC Officially Announces Dow Sponsorship Deal,” July 17, 2010, http://www.olympics-now.com/2010/07/17/ioc-officially-announces-dow-sponsorship-deal [August 18, 2010]; and, "IOC Announces Sponsorship Deal with Consumer Products Giant Procter \& Gamble," YAHOO! News Canada, July 28, 2010, http://ca.news.yahoo.com/s/capress/100728/business/oly_ioc_sponsor [July 28, 2010].

${ }^{20}$ The point-counterpoint argument is captured well by Philip Hersh in his Globetrotting blog posted to chicagotribune.com on July 8, 2009. The blog focused on Hersh's e-mail exchange with Hein Verbruggen, one of the IOC members tasked by IOC President Jacques Rogge to conclude an agreement with the USOC, and one of the more strident Europeans seeking a reduction in the USOC's share of IOC-generated commercial revenue. See Philip Hersh, "Verbruggen on IOC-USOC Money Flap: Never a Serious Proposition from USOC," chicagotribune.com, July 8, 2009, http://newsblogs.chicagotribune.com/sports_ globetrotting/2009/07by-philip-hersh-over-the-past-several-months-I-have-written-severalblogs-about-the-ongoing-revenue-sharing-dispute-between.html [August 18, 2010].

${ }^{21}$ For the development of the Rome Formula and IOC President Avery Brundage's hopes that such a formula would satisfy the NOCs, ISFs, and OCOGs, all of whom lobbied for large shares of the television revenue in the 1960s, see Stephen R. Wenn, "An Olympian Squabble: The Distribution of Olympic Television Revenue, 1960-1966,” Olympika: The International Journal of Olympic Studies III (1994): 27-47.

${ }^{22}$ For instance, Willi Daume, President of the Munich OCOG, signed a deal for U.S. television rights with the American Broadcasting Company for $\$ 13.5$ million. However, at this time, the OCOGs negotiated the contracts and the IOC merely approved them. Daume inserted a clause that classified $\$ 6$ million of this total as a technical services fee payable directly to the OCOG. Hence, the contract set $\$ 7.5$ million as the rights fee divisible accord- 


\section{SAIS Review WINTER-Spring 2011}

ing to the Rome Formula. Daume's move resulted in a standoff, but the IOC eventually acquiesced when Munich agreed that a technical services fee could be included only in the contract for the U.S. market. The IOC was neither in a position to transfer the Games to another city nor withstand a lengthy impasse because of its dependence on the receipt of a share of the U.S. contract to fund its operations. See Stephen R. Wenn, "Growing Pains: The Olympic Movement and Television, 1966-1972," Olympika: The International Journal of Olympic Studies IV (1995): 1-22.

${ }^{23}$ Barney, Wenn, and Martyn, Selling the Five Rings, 103-150, 181-202.

${ }^{24}$ Minutes of the Meeting of the IOC Executive Board, Lausanne September, 24-26, 1995, pp. 45-46, IOCA. On this assertion, Pound proved prescient as the USOC was quick to lobby for more money. When they USOC met resistance, Colorado Springs officials took their case to Washington in search of support from Congressional allies. They wanted law makers on Capitol Hill to decree that U.S. television contracts should be negotiated by the USOC, which could then establish its own share of the money independent of the IOC's input. The USOC had launched a similar campaign in 1990 through Representative Tom McMillen (D - Maryland), but Pound headed off further legislative action through a personal meeting with McMillen in Washington in January, 1991. It should be noted that the change in the IOC's share was only one of the drivers behind the USOC's campaign on Capitol Hill in 1996. In 1995, USOC officials were angered by the IOC's pursuit of long-term U.S. television rights agreements with NBC for 2000/2002 and 2004/2006/2008 while the USOC was still limited to a 10 percent share. In 1996, Samaranch had been willing to move as high as 15 percent for the USOC, but he was angered by news of the lobbying efforts of USOC officials on Capitol Hill. He chastised USOC leaders at an IOC/USOC Summit in Cancún, Mexico in October, 1996, and he informed USOC representatives that he was prepared to move forward without the USOC. This could only have been a veiled threat given the financial realities of the U.S. market for the Olympic Movement, and cooler heads prevailed. This skirmish resulted in the bilateral agreement that the USOC's share would increase to 12.75 percent for the 2004 Olympics and beyond. The former distribution plan permitted the USOC access to 10 percent of the U.S. television contract, with the members of the Olympic Tripartite (IOC, ISFs, and NOCs) sharing 30 percent. The OCOG received the majority share, 60 percent. Once the IOC Executive Board approved the shift to a 51 percent share for the Olympic Movement, the USOC, as noted, looked for an increase to its 10 percent share. Richard Pound proposed the 12.75 percent solution as it would maintain the USOC's one-quarter share of money dedicated to members of the Olympic Movement, but not sacrifice (from an IOC perspective) the additional 2.25 percent that Samaranch had been willing to concede to the USOC. Barney, Wenn, and Martyn, Selling the Five Rings, 262-265; and, Richard Pound, e-mail message to Stephen Wenn, September 25, 2010.

${ }^{25}$ Ibid., p. 46.

${ }^{26}$ Ibid.

${ }^{27}$ Ibid., p. 45.

${ }^{28}$ Ibid., p. 46

${ }^{29}$ Ibid., p. 47.

${ }^{30} 2010$ Olympic Marketing Fact File (IOC: Lausanne, 2010), 9. One must wonder why, for instance, an OCOG must still pay for the transportation, accommodation, and uniforms for judges, referees, and technical officials at an Olympic festival and why that expense does not fall to the individual sport governing bodies given the money flowing to their respective coffers. The OCOG, at its expense, must also provide the ISFs with "the premises and facilities necessary for processing matters of a technical matter." These policies are aspects of By-law to Rule 47 and By-law to Rule 41 of the Olympic Charter. IOC Reference Service, e-mail message to Stephen Wenn, September 8, 2010. Summer ISFs participating in Barcelona (1992) shared \$37.6 million, while those participating in Beijing shared \$295 million. Winter ISFs participating in Albertville shared $\$ 17$ million, while those operating in Turin (2006) split \$126 million. These data reveal a 7.8- and 7.4-fold increase respectively.

${ }^{31}$ It should be noted that the cost of transporting athletes has been borne by OCOGs on occasion in the past when such remuneration has been used as an element of a city's bid as a means of garnering support. 
${ }^{32}$ A proactive approach to revenue distribution whereby the OCOG share of revenue is enhanced might have important tangible benefits beyond what we suggest, namely the extended use of Olympic competition venues. The IOC hardly wants to revisit a time in which the number of bid cities dwindles. In the 1970s and 1980s, this circumstance resulted from bid city wariness as a result of world geopolitics, the hazards of the boycott era, and the prospect for crushing debt (witness Montreal, 1976). We see our suggestion to elevate the OCOG share of Olympic television and corporate sponsorship money as a wise 'stimulus plan' to offset any chilling effect on future bids resulting from the challenges faced by numerous economies in the new global order.

${ }^{33}$ Admittedly, this assertion poses a significant challenge to the history and tradition of U.S. government practice concerning public money and USOC funding. And, the USOC appreciates its ability to conduct its affairs in the absence of government money as it aids in the maintenance of its operational autonomy. Still, it is an argument that receives little hearing in Europe or other regions of the Olympic world.

${ }^{34}$ In the 1980s, one of the contributing factors leading to the original IOC/USOC agreements concerning revenue had to do with the threat of a Washington-imposed Olympic tax on U.S. money directed to Lausanne for distribution throughout the Olympic Movement. The IOC believed it was better to pursue agreements with the USOC in which it had some control on the amount of money flowing to the USOC, as opposed to a U.S. federal tax which could be adjusted by Congress over time, likely to the IOC's detriment.

${ }^{35}$ Evidence for the merit of this proposal can be found in the IOC's own literature. See "Young People at the Heart of the Forum on Sport, Peace and Development," Olympic.org, April 24, 2009, http://www.olympic.org/media?articleid=72369 [January 14, 2011].

${ }^{36}$ The Millennium Development Goals were established by the United Nations in 2000 to address major issues facing developing nations by 2015. The eight Millennium Goals include ending poverty and hunger, providing universal education, championing gender equity, enhancing child and maternal health, combating AIDS/HIV, promoting environmental sustainability, and establishing global partnerships for development.

${ }^{37}$ Currently, the eleven TOP Sponsors include (category in parentheses) Coca Cola (nonalcoholic beverage), Acer (computing equipment), Atos Origin (IT/communications), Dow Chemical (chemistry), GE (electronics), McDonalds (retail food), Omega (time pieces), Panasonic (audio/TV/video), Proctor \& Gamble (personal care/household items), Samsung (wireless communication), and Visa (consumer payment).

${ }^{38}$ Such a commission might follow the composition model set by the IOC when it established the Ethics Commission in wake of the Salt Lake City bid scandal that invites significant contribution from non-IOC members (for an extended analysis, see Wenn, Barney and Martyn, Tarnished Rings: The International Olympic Committee and the Salt Lake City Bid Scandal). This commission, as with the IOC Ethics Commission, would be chaired by a non-IOC member. 